症例

術前に局在診断しえた原発性アルドステロン症の 2 治験例

大阪市立大学第 1 外科（主任：梅山䌘教授）

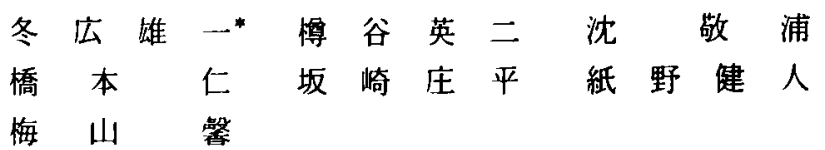

同 第 1 内科（主任：武田忠直教授）

別府敬三堀千恵

\title{
TWO CASES OF PRIMARY ALDOSTERONISM
}

Yuichi FUYUHIRO, Eiji TARUYA, Keiho SHIN, Hitoshi HASHIMOTO,

Shohei SAKAZAKI, Kenjin KAMIKO and Kaoru UMEYAMA

The First Department of Surgery, Osaka City University, School of Medicine, Osaka

(Director : Prof. Kaoru UMEYAMA)

Keizo BEPPU and Chie HORI

The First Department Internal Medicine, Osaka City University, School of Medicine, Osaka

(Director : Prof. Tadanao TAKEDA)

原発性アルドステロン症は1955年 Connにより初めて記戴されて以来，厷く認められ るようになった疾患であるが，著者らは腺腫による原発性アルドステロン症の 2 例を経 験したので，若干の考察を加えて報告する。

症例 $1 ： 49$ 歳, 女性, 術前血圧 210-100mmHg, 血清 $\mathrm{K} 2.6 \mathrm{mEq} / \mathrm{L}$, 血中フルドステロ ン值 $1.600 \rho \mathrm{g} / \mathrm{ml}$ 以上で, 副腎シンチグラムで右副腎に著明な RI の集積, 動脈撮影にて 右副堅に tumor stain を認めたが, 副腎静脈血 sampling によるアルドステロン値は, 両 側とも $1,600 \mathrm{\rho g} / \mathrm{ml}$ 以上と scale over を示し，これによる局在診断は不能であった，摘 出した右副肾腫場は，大きさ， $3.5 \times 3.0 \times 2.0 \mathrm{~cm}$, 重量, $10.5 \mathrm{~g}$ の腺腫であった。

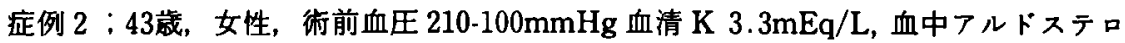
ン值 $124.0 \rho \mathrm{g} / \mathrm{ml}$ で, 副腎シンチグラムで左副腎に RIの集積, 動脈撮影にて左副腎に tumor stkin を認め, 副腎静脈血 sampling では，左副腎静脈血中フルドステロン値のみ かi $1,600 \rho \mathrm{g} / \mathrm{ml}$ と異常高値を示し, 本症例では副腎静脈血 sampling に上り患側を診断し えた。摘出した左副腎腫場は，大きさ， $1.9 \times 1.5 \times 1.5 \mathrm{~cm}$, 重量, $2.5 \mathrm{~g}$ の腺腫であった。

2 症例とも術前の局在診断に成功し，また腫晹摘出により血中アルドステロンの正常 化，高血圧および低 $\mathrm{K}$ 血症の改善が認められ，外科的治療が奻を奏した症例であった。

綁 言

原発性アルドステロン症は，最近では決して稀な症 患とはいいにくい，しかし本症類似の疾患は多くあり
その鑑別には十分な注意が必要である。とくに病変の 局在診断は外科的治寮を行ら上に重要である。われわ れは最近術前に畽碍の局在を診断しえた本症の 2 治験 例を経験したので報告する。

•大阪市立大学第 1 外科大学院生 
表 1 症例 1

\begin{tabular}{|c|c|c|c|c|c|c|}
\hline \multicolumn{4}{|c|}{ 入院時臨床検查成繒 (I) } & \multicolumn{3}{|c|}{ 入院時臨休検查成績 ( I ) } \\
\hline WBC & 5800 & ALP & 9.3 & 血中コーチソール & 15.9 & $(10 \sim 15)$ \\
\hline RBC & 341 万 & $r \mathrm{GTP}$ & 8 & 尿中17 KS & 2.0 & $(1 \sim 8)$ \\
\hline $\mathrm{Hb}$ & $11.0 \mathrm{~g} / \mathrm{dl}$ & LAP & 15 & 尿中 $170 \mathrm{HCS}$ & 7.2 & $(2.4 \sim 6.4)$ \\
\hline $\mathrm{Ht}$ & $32.6 \%$ & $\mathrm{LDH}$ & 257 & 血中カテコールアミン & & \\
\hline 血小板 & 12.4 万 & ICG 15分値 & $17 \%$ & NA & 0.11 & $(0.04 \sim 0.35)$ \\
\hline 出血時間 & $3^{\prime} 30^{\prime \prime}$ & 空腹時血糖 & $83 \mathrm{mg} / \mathrm{dl}$ & A & 0.05 & (0.12 以下) \\
\hline 该固時間 & $8^{\prime}$ & 血清電解質 & & 尿中総カテコールアミン & 27.5 & $(0 \sim 100)$ \\
\hline 総蛋白 & $7.3 \mathrm{~g} / \mathrm{dl}$ & $\mathrm{Na}$ & $149 \mathrm{mEq} / \mathrm{L}$ & NA & 23.1 & $(0 \sim 50)$ \\
\hline albumin & 60.496 & K & $2.6 \mathrm{mEq} / \mathrm{L}$ & A & 4.4 & $(0 \sim 10)$ \\
\hline$\alpha_{1}$ globulin & $3.1 \%$ & $\mathrm{Cl}$ & $112 \mathrm{mEq} / \mathrm{L}$ & VMA & 1.1 & $(2 \sim 10)$ \\
\hline$\alpha_{2} \quad \prime$ & 8.496 & $\mathrm{Ca}$ & $5.0 \mathrm{mEq} / \mathrm{L}$ & 血中アルドステロン 16 & $600 \mathrm{pg} / \mathrm{n}$ & 上 $(10.9 \sim 62.7)$ \\
\hline$\beta \quad \prime$ & $9.7 \%$ & $P$ & $2.9 \mathrm{mg} / \mathrm{dl}$ & 尿中アルドステロン 10 & $04.53 \mu \mathrm{g}$ & 以上(2 20) \\
\hline$"$ & $18.5 \%$ & BUN & $41 \mathrm{mg} / \mathrm{dl}$ & レニン活性(安静時) & 0.92 & \\
\hline TTT & 3.2 & Creatinine & $2.3 \mathrm{mg} / \mathrm{dl}$ & & & 勺は正常值を示す \\
\hline ZTT & 8.4 & PSP 15 分值 & $4 \%$ & & & \\
\hline 総ビリルビン & $0.5 \mathrm{mg} / \mathrm{dl}$ & 120 分値 & $20 \%$ & & & \\
\hline GOT & 25 & GFR & $27 \mathrm{ml} / \mathrm{min}$ & & & \\
\hline GPT & 24 & RPF & $43 \mathrm{ml} / \mathrm{min}$ & & & \\
\hline $\mathrm{CHE}$ & 0.81 & RBF & $63 \mathrm{ml} / \mathrm{min}$ & & & \\
\hline
\end{tabular}

\section{症例}

症例 1 患者: 森 $\bigcirc$ 綂 $\bigcirc, 49$ 歳, 女性 (会社員). 主訴：特になし.

家族歴：特記すべきことなし。

既往歴：昭和 54 年 9 月子宮筋腫にて子宮全摘術を受 けている。

現病歴：自覚症状は全く認められなかったが，子宮 全摘術を受けた際，その術前検查にて高血圧および腎 機能不全を指摘され，精査目的にて本院第 1 内科を受 診，諸検査の結果原発性アルドステロン症，およびの う胞腎と診断され，手術目的にて昭和 55 年 6 月9日当科 に転科した。

入院時現症：体格・栄養中等度. 顔貌正常にて浮尰 は認めず．負血，黄疽なく，血圧 $210 〜 100 \mathrm{mmHg}$. 心 音・呼吸音正常. 腹部は平坦で軟く肝脾触知せず。下 腹部正中に手術症痕が認められた。そのほか異常腫瘤 などは触れなかった。下腿には浮腫る認められなかっ た。

入院時検査成績：（表 1） 軽度の貧血みられ，血 清電解質は, $\mathrm{K} か 32.6 \mathrm{mEq} / \mathrm{L}$ と著明な低下を示した。 堅機能検查では, BUM 41, クレアチニン $2.3 \mathrm{mg} / \mathrm{dl}$, PSP 15 分值 $4 \%$, 120 分値 $20 \%$, GFR 27, RPF 43, RBF $63 \mathrm{ml} / \mathrm{min}$ と腎機能の低下がみられた。

副腎機能検査では，血中コーチソール，尿中 $17 \mathrm{KS，}$ 17OHCS, 拈よび血中, 尿中カテェールアミンはともに
正常範囲にあったが, 血中アルドステロン $1,600 \rho \mathrm{g} / \mathrm{ml}$ 以上，尿中アルドステロン $104.53 \mu \mathrm{g} / \mathrm{day}$ 以上と著明 な高値を示した，しかし，レニン活性は正常範井内に あった。

副腎シンチグラム検査：(図 1) ${ }^{131} \mathrm{I}$-アドステロー ルによる副腎シンチグラムでは，右副腎に著明な RI の集積像と尰大像がみられ，右副腎の hyperfunction からかがわれた。

堅動脈造影：（図 2 ）右腎動脈により分䐈した右副 腎動脈は太いが血管増生は細微であり，静脈相では边

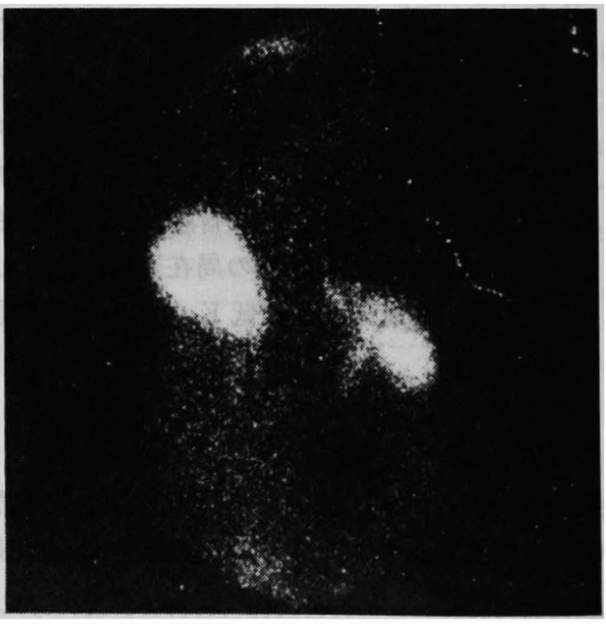

図 1 副祭シンチグラム（症例 1） 


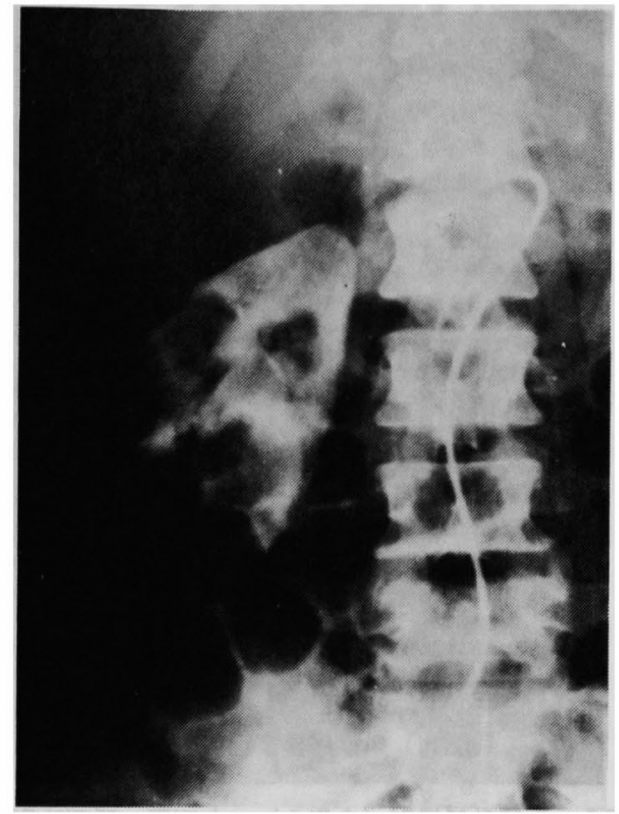

図 2 叒動脈撮影（症例 1）右堅上極より離れて淡 い連痬陰影を認める。

緑明瞭な $4.0 \times 3.5 \mathrm{~cm}$ 大の tumor stain がみられた。 た腎動脈末梢枝には圧排伸展像がみられた。

汉静脈血 samplingによるアルドステロン值の測 定：左右の腎静脈および下大静脈血を sampling, その アルドステロン値を測定したが，いずれす $1,600 \rho g / m l$ 以上で scale over となり病变の局在診断には役立た なかった。

Renogram：左右留とも peak はなく，直線状で無 機能な patternを示し, Renocintigram でも両側腎と むRIの集積が低く，不整形で欠損像が認められた。

腹部エコーおよびCT 検查：両側腎はともに腫大 し，堅内に多数ののう胞様欠損像がみられたが，副腎 の病変像は，両検査とも描出されなかつた。

以上の所見より右副腎腺腫による原発性フルドステ ロン莚およびのう胞腎の診断にて、スピノロラクトン $400 \mathrm{mg} /$ day を投与，血圧 $120-84 \mathrm{mmHg}$ ，血中 $\mathrm{K} 4.2$ $\mathrm{mEq} / \mathrm{L}$ となった時点にて手術を施行した。

手術所見：右旁正中切開で経腹膜的に後腹膜に到達 した. 腫瘍は右堅上極上り約 $5 \mathrm{~cm}$ 上方の後腹膜脂肪内 に略円形の拇指頭大の腫瘤として触れ，庱着もなかっ たので容易に摘出しえた。

摘出標本は，大きさ $3.5 \times 3.0 \times 2.0 \mathrm{~cm}$, 重量 $10.5 \mathrm{~g}$ で 良く被膜に拈㧍われた弾性軟の腫瘤で, 割面ではいわ

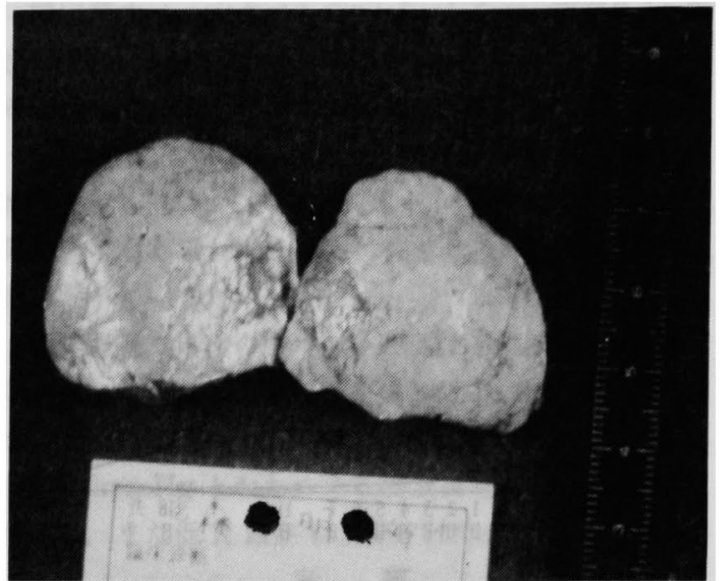

図 3 摘出標本割面（症例 1$)$

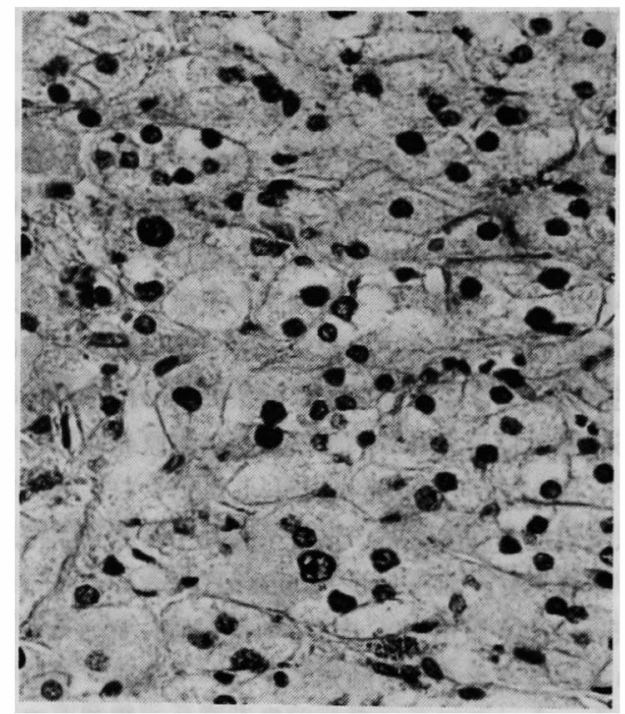

因 4 症例 1 の組織像（×2 000$)$

ゆる golden yellow の色調を呈していた（図3）. 病理組織学的には大小さまさまな類円形の核を持 ち、また原形質る極めて豊富な明るい細胞が充実性の 増殖を示していた。しかし異型性は認められず良性の 腺腫と診断した（図4）。

術後経過は良好で, 血中アルドステロン値は, 術值 後 $1,280,1$ 時間後 $1,040,8$ 時間後 $600 \rho \mathrm{g} / \mathrm{ml}$ 之漸次低 下を示し, 約 1 力月後には $53 \rho \mathrm{g} / \mathrm{ml}$ と正常範囲内に拉 ちついた(表 2 ). 血压も 118 80 $\mathrm{mmHg}$ で以後血圧の 上昇をみることはなく，また低 $\mathrm{K}$ 血症す改善された。

症例 2 患者：杉 $\bigcirc$ 美 $\bigcirc, 43$ 歳, 女性（主婦)。 
表 2 術後血中アルドステロン佂の推移

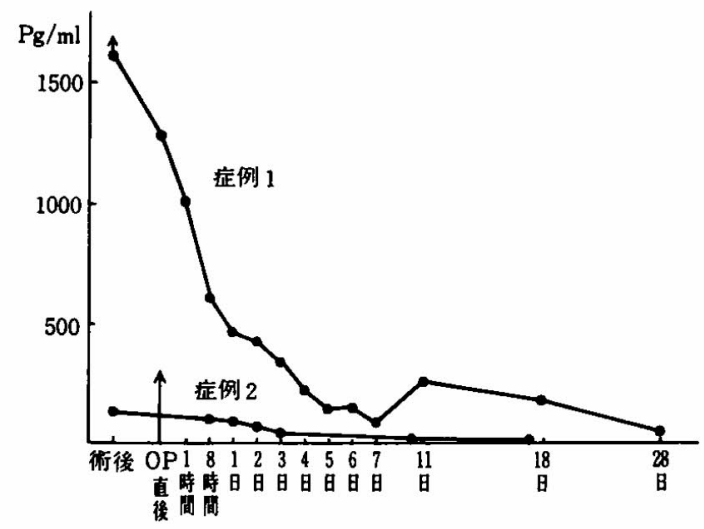

主訴：左耳鳴。

家族歴：父が脳溢血にて死亡.

既往歴：特記すべきことなし。

現病歴：昭和52年 6 月左耳鳴を訴えて近医を受診, 高血圧症 $(210 \sim 100 \mathrm{mmHg})$ と診断され治療を受けて いた。この間多尿，口渴なく，下駺浮腫す認めていな い.高血圧はあまり改善されず経過していたが，昭和 54年12月18日と 23日に，短期間の意識消失，咽吐が発 来したため，本院第 1 内科を受診，降王利尿剂等にて 通院治療を受ける 高血圧は軽快せず，精査のため昭 和55年 8 月 12 日入院し, 諸検查の結果原発性アルドス テロン症と診断され当科に転科した。

人院現症：顔貌正常.体格・栄盖中等度.脈拍, 78 整, 贀張良好. 血圧 $170 \sim 100 \mathrm{mmHg}$ (スピノロラクト ン $75 \mathrm{mg}$ /day 服用中). 皮膚, 口腔粘膜に異常なし. 全 身の表在性リンパ節も触知しえない，負血，黄疽もな い. 胸部には理学的に異常所見むなく，腹部も平坦・ 軟で肝・脾・腎いずれる触知せず，腫瘍も触れなかっ た.また下肢の浮腫も認めなかった。

入院時検查成繶：血清電解質では， $\mathrm{K} か 33.3 \mathrm{mEq} / \mathrm{L}$ で軽度の低下がみられ，GFR 63, RPF 289, RBF 439 とわずかな低下を示したが，BUN，クレアチニンは正 常であった。

副腎機能検査では，血中コーチソール，尿中 $17 \mathrm{KS，}$ 17OHCS，および尿中総カテコールアミンはともに正 常範囲であったか，血中アルドステロン $124.0 \rho \mathrm{g} / \mathrm{ml}$, 尿中アルドステロン $30.6 \mu \mathrm{g} / \mathrm{day}$ と高值を示した。レ ニン活性は0.84 と正常範囲内にあった。

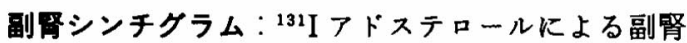
シンチグラムでは，右副堅は描出されず，左副腎に RI

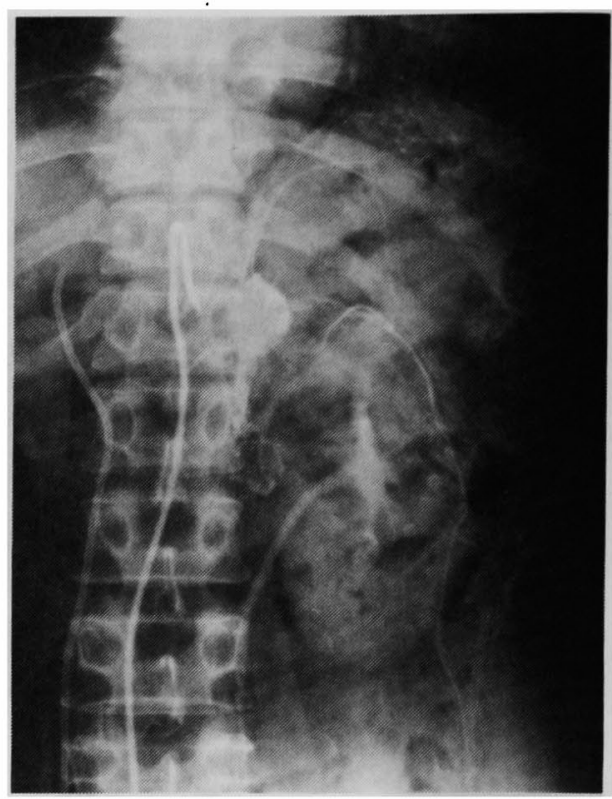

図 5 副腎動脈撮影（症例 2）左副腎に重瘍陰影を 認めた。

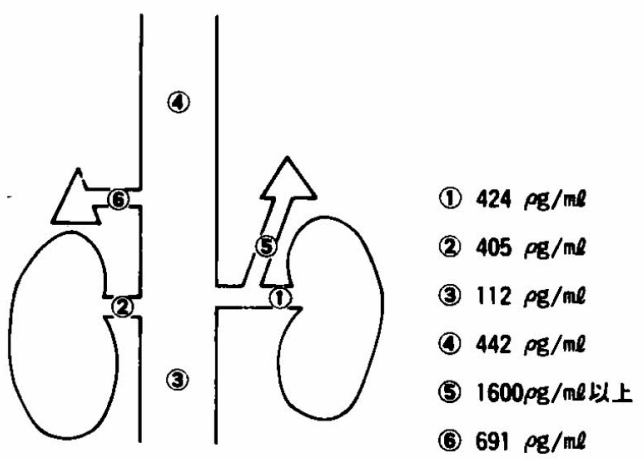

图 6 副腎および䞍静脈血 sampling によるアルドス テロン値の測定（症例 2 ）左副腎静脈血のみ異常 値を示した。

の異常集積像が認められた。

副睛動脈撮影：左堅動脈起始部に分岐される左副堅 動脈は比較的細く, 正常とかわりなかったが, 静脈相 では, 約 $2.5 \times 1.7 \mathrm{~cm}$ の tumor stain, pooling が認めら れた。右副腎動脈相では tumor stainは認められな かった（図 5 ).

副霄およひ腎觧脈血 samplingによるアルドステロ ン値の測定：左副腎静脈血で $1,600 \mathrm{~g} / \mathrm{ml}$ 以上と, 異常 高値を示した.なお左腎静脈では424, 右堅静脈405, 下大静脈下流 112 , 上流 442 , 右副腎静脈 $691 \rho \mathrm{g} / \mathrm{ml}$ て 


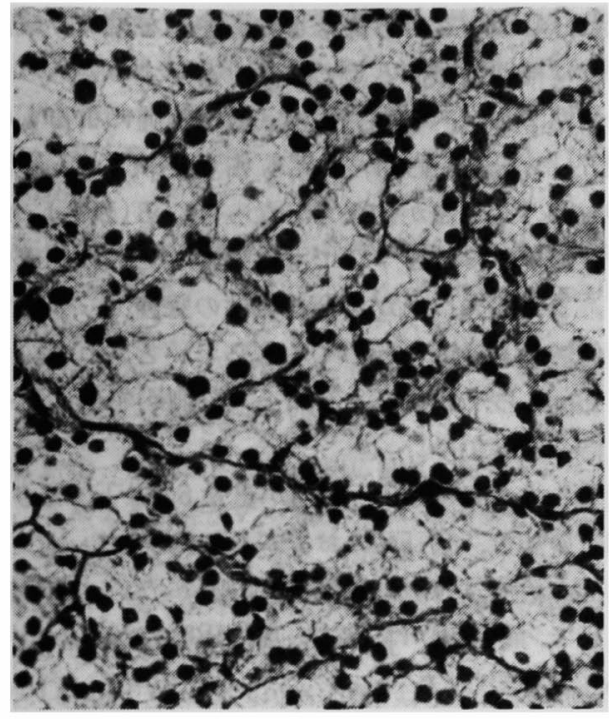

图 7 症例 2 の組織像 $(\times 200)$

\section{あった(図 6 ).}

Renogram, DIP：ともに異常所見は認められな かった.

腹部エコー, CT 検査：ともに副腎腫湯像は描出さ れなかった。

以上の所見により，左副腎腫煌による原発性フルド ステロン症と診断し、スピノロラクトンを $75 \mathrm{mg} / \mathrm{day}$ 連日投与した。血圧 $140 \sim 100 \mathrm{mmHg}, \mathrm{K} 4.7 \mathrm{mEq} / \mathrm{L}$ と なった時点で手術を施行した。

手術所見左旁腹直笳切開で経腹膜的に後腹膜腔に入 ク，脾を翻転したのち左腎上極直上の後腹膜脂肪組織 内に拇指頭大の畽瘤を認めた。睡瘤と周囲との瘜着は 認められず，容易に摘出できた。
摘出標本は，大きさ $1.9 \times 1.5 \times 1.5 \mathrm{~cm}$, 重量 $2.5 \mathrm{~g} て ゙$ 良く被膜にお扔われた弾性軟の腫瘤で，割面はいわゆ る golden yellow の色調を呈していた。

病理組織学的には, cortex に似た原形質が泡沫状の 増殖を示し，極めて明るい胞体を有する細胞から成り， 異型性は認められなかった。良性の腺腫の所見であっ た（図 7 ).

術後経過：術後の血中アルドステロン値は, 手術当 日 $100 \rho \mathrm{g} / \mathrm{ml}, 1$ 日目 $91.7,2$ 日目 $69.5,3$ 日目 $42.8 \rho \mathrm{g} /$ $\mathrm{ml}$ と 3 日目で正常範囲内におちつき（表 2 )，血圧む 124 80 $\mathrm{mmHg}$ とおちつき以後上㫒をみることもなく 経過し，また低 $\mathrm{K}$ 血症も改善された。

\section{考案}

原発性アルドステロン症の診断基準は，アルドステ ロン分泌の増加，レニン抑制，17KS, $17 \mathrm{OHCS}$ の正常 を確認することとされているが，今日ではこれらの湘 定法む確立され，内科的診断も比較的容易になりつつ ある。

外科的立場からは，本症の診断とともに，その局在 診断が重要な役割りを占ると思われる，以前は，後腹 膜気充法が行なわれていたが，その診断的価置は低く， また患者に対する苦痛す大きく行なわれていない，そ れにかわって最近の局在診断の方法としては, 副腎動 静脈造影法, 副腎シンチグラフィ，ならびに副腎静脈 血中アルドステロン值の測定が主たるるのとなってき ている.

血管造影法では，副腎動脈は左右各 3 本に分かれて いるため，選択的に動脈造影を行なっても副腎全体の 血管像を知ることがむずかしいことが多く，打田1" 静脈は䯣質中の太い 1 本の中心静脈に流入するところ から，副腎静脈造影法の有効性を述べている，また大

表 3

原発性了ルドステロン症の主な報告例とその副骨病変頻度

\begin{tabular}{|c|c|c|c|c|c|c|c|c|c|}
\hline 報告者 & 年 度 & 症例数 & 腺 & 腫 & 癗 & 過 & 形成 & $\xi$ & 他 \\
\hline Conn ${ }^{10)}$ & 1961 & 118 例 & 108 例 & $(91.5 \%)$ & & 9 例 & ( $7.6 \%)$ & 1 例 & $(0.9 \%)$ \\
\hline 鳥 眮 ${ }^{111}$ & 1969 & 215 例 & 189 例 & $(87.996)$ & 2 例 $(0.9$ 果) & 24 例 & (11.2\%) & & \\
\hline 熊谷 ${ }^{12)}$ & 1973 & 307 例 & 219 例 & $(71.3 \%)$ & 5 例 (1.6名) & 68 例 & (22.1\%) & 15 例 & $(5.0 \%)$ \\
\hline 中䳋 13) & 1977 & 30 例 & 27 例 & $(90.0 \%)$ & & 3 例 & $(10.0 \%)$ & & \\
\hline
\end{tabular}

副堅腺腫報告例

\begin{tabular}{|c|c|c|c|c|c|c|}
\hline 報告者 & 年 度 & 应例数 & 男女比 & 30才 40才台頻度 & 腺腫重量 $6 \mathrm{~g}$ 以下制度 & 単発片側性頻度 \\
\hline Conn ${ }^{14)}$ & 1964 & 145 例 & $1: 2.6$ & $72.0 \%$ & $68.0 \%$ & $91.0 \%$ \\
\hline 鳥 飼 ${ }^{(1)}$ & 1969 & 189 例 & $1: 1.7$ & $80.0 \%$ & $82 \%$ & $95.3 \%$ \\
\hline 熊谷 ${ }^{12)}$ & 1973 & 219 例 & $1: 1.7$ & $73.0 \%$ & $?$ & $98.6 \%$ \\
\hline
\end{tabular}


動脈内に比較的多量の造影剂を注入すると副腎実質の 全体を描出することができる．今回の 2 症例です動脈 造影の静脈相より副堅の性状をとらえることができ た.

副腎静脈撮影と同時に施行しらる副堅静脈および腎 静脈血 sampling によるアルドステロン値の測定はそ の局在を知る上に極めて効果的で，福地 ら² は，両側副 腎静脈を採取しえた 9 例の全例に局在診断が可能で あったと述へ，自験例の症例 2 す本法によって確診し えた。 また右副腎静脈へのカテーテルの揮入は左側に 比べて困難なことが多いが，福地ら゙2は1側の副腎静 脈血の採取でも局在診断が可能であったと述べてい る、また本邦では95\%以上が単発片側性であることよ ク，1側の副腎静脈のみのカテーッル挿入に終った場合 でも，ある程度の局在診断が可能であると思われる。

しかし, 症冽 1 の如く末梢血中のアルドステロン值が, $1,600 \mathrm{\rho g} / \mathrm{ml}$ 以上と scale overを示すよ 5 な症例で は，局在診断が不可能な場合があることが判明した。

最近とくに局在診断上有用視されているのは, 副堅 シンチグラムである. 1971年, Beierwaltes ら゙によっ て開発された ${ }^{131}$ I-19-Iodocholesterol を用いた副腎シ ンチグラムが応用されるように至って，副腎皮質腫場 の局在診断は一層進歩して来た，中鴄ら”は13例の原 発性フルドステロン症の患者に本法を用いた副腎シン チグラムを施行し，9例（70\%）に董晹像が描出され 局在猃断に成功している，本法を用いたわれわれの症 例も10.5g，2.5g の腺腫であったが何れも局在診断に 有效であった。しかし，小さい腫煬では腫瘍像が描出 されない例もあるようで中嶋”の13例中 4 例でも $1 \mathrm{~cm}$

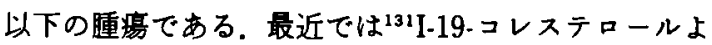
ク一㕣少ない量で副腎病変を描出しらるとされてい

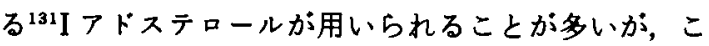
の方法によってもなお描出不能な症例や，両側同程度 の描出例のあることが指摘されている(文. 福永ら $5^{6)}$, 宮 崎 ら゙), 古田ら シンチクラムの有用性をあげているが，やはり $1 \mathrm{~cm}$ 以 下の尰掦では描出は困難なことが多い上らである。し かしこれらのンンチグラムは患者にはとんど苦痛を 与えずスクリーニングしして，非常にすぐれた方法と いえよ5.

局在診断の補助診断法として，立松9は超音波工 コーにより最小 $1.0 \mathrm{~cm}$ の睡湯を含む11症例の局在診 断に成功し，その有用性を強調しているか，われわれ の 2 症例では超音波ェコーにての診断には成功しな
かった、しかしこの方法もさらに症例を重ね，模討を 加えれば補助診断法として大きく進歩するであろう。

原発性アルドステロン症は一般に腺腫によるるのが 圧倒的に多く，約70 90\%も占め，次いで過形成 10.0 22.1\%, 癌が約 $1 \%$ となっている(表 3). 最も

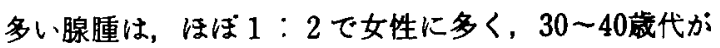
多い．また $95 \%$ 以上が単発片側性の腺嗹で，多発また は両側性のすのはきわめてめずらしいとされている。 またConn ら (4)の指摘する如く, 左側が右側に比べて 約 2 倍の頻度で多い。

腺腫の大きさは，60８0\%が重量 $6 \mathrm{~g}$ 以下であり，本 症例 1 の如く, $10.5 \mathrm{~g}$ におよぶすのは少ない。

本症の治療は外科的腫腸摘出以外にない，その成樍

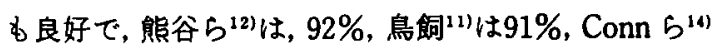
は95\%と報告している。

たた血清電解質は約 1 週間で回復するが，一部の症 例では高血圧の持続する症例も認められることから， 少なくとも術後䄪 1 年は, 経過観察が必要といら報告 むある(5)16)181. また，熊谷ら ${ }^{(2)} は 219$ 例のちち，2 例に 再発のあったことを述べている.

なお過形成による原発性アルドステロン症の外科的 治療成績は腺腫ほど良好でなく，また原因が明らかに されていない特発性フルドステロン症についての外科 的治療の有効性については論議のあるところである。

\section{結論}

われわれは，腺腫による原発性アルドステロン症の 2 例を経験し, 術前の局在診断では, 血管撮影, 副腎 静脈血 sampling, 副堅シンチグラムが有効であった。 腺腫重量は $2.5 \mathrm{~g}, 10.5 \mathrm{~g} て ゙, 2$ 例ともに外科的治療によ り，高血压および電解質異常は著明に改善された。

尚, 本論文の要旨は第330回大阪外科集談会にて発表し た。

\section{文嗝}

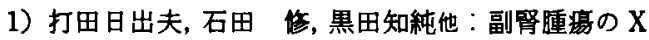
線診断，臨放，19：513-526，1974。

2）福地総逸，中嶋峈夫，春山和見：副䍿静脈血中フル ドステロン含量測定，日本臨床，37：1197-1198， 1979.

3) Beierwalten, W.H., Lieberman, L.M., Ansari, A. $N$., et al.: Visualization of human adrenal glands in vivo by scinti-llation scanning. J.A.M. A., $216: 275-277,1971$.

4）中嶋凱夫，福地総逸，竹内孝彦他：原発性フルド テロン症の副腎スキャンニンクによる局在診断. 日本臨床, $33: 448-452,1975$. 
5）福地総逸, 中嶋凱夫，三浦 正他：新しい副腎ス

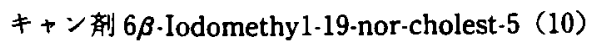

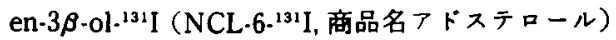
の臨床経験, ホルモンと臨床, $23 ： 1051-1056$, 1975.

6）福永仁夫, 土光茂治, 山本逸雄他: ${ }^{131}$ IAdo-sterol による副腎ンンチグラフィー, Redioisotopes, 26 : 864-868, 1977.

7）宮崎麻知子, 山崎統四郎：副腎シンチグラム, 臨 放, $21: 555-556,1976$.

8）古田豊，榎野 新, 满田広樹他：副腎シンチグラ ムによる原発性フルドステロン症の局在診断, 広 島医学, $32: 483-487,1979$.

9）立松 輝：副腎腫場の超音波による局在診断，日 内分泌会誌, 52：1111-1125，1976.

10) Conn, J.W. and Conn, E.S.: Primary aldosteronism versus hypertention disease with secondary aldosteronism. Recent Progress in Hormone Renearch, $17: 389-414,1961$.

11）11）鳥飼能生：高血压と内分泌, 日内会誌，58： 579-592, 1969.
12）熊谷 朗, 山本昌弘, 田村 泰他：本邦における過 去10年間の原発性フルドステロン症307例の実態， 日内分泌会誌，49：1362-1378， 1973.

13）中嶋凱夫, 福地総逸：原発性アルドステロン症, 内 科シリーズ, 31：120-131，南江堂，1978.

14) Conn, J.W., Knopf, R.F. and Nesbit, R.M. : Clinical characteristics of primary aldosteronism from an analysis of 145 cases. Am. J Surg., $107:$ 159-172, 1964.

15) Conn- J.W.: The evolution of primary aldosteronism, Harvey Lecture, 62 : 257-291, 1967.

16) Biglieri,E.G., Schambelan, M., Slaton, P.E., et al. : The intercurrent hypertension of primary aldosteronism, Supplement to Circulation Research, Vols. XXVI and XXVII : I-195-I $-202,1970$.

17) Melby, J.G.: Case records of the Massachusetts Genemal Hospital. New Engl. J. Med., $287: 656-663,1972$. 